Peranan MGMP Sosiologi

\title{
PERANAN MUSYAWARAH GURU MATA PELAJARAN (MGMP) SOSIOLOGI DALAM MENINGKATKAN KOMPETENSI PROFESIONAL GURU SMA
}

\author{
Rizkia Waluyanti ${ }^{1}$
}

\begin{abstract}
Abstrak
Tujuan penelitian ini adalah untuk mengetahui bagaimana peranan Musyawarah Guru Mata Pelajaran (MGMP) Sosiologi dalam meningkatkan kompetensi profesional guru sosiologi SMA di kabupaten Sleman dengan merencanakan dan melaksanakan program kerjanya agar guru sosiologi dapat dikatakan sebagai pendidik yang profesional dibidangnya.

Penulisan skripsi ini menggunakan jenis penelitian kualitatif deskriptif. Sumber data diperoleh dari hasil wawancara, dokumentasi dan kepustakaan. Wawancara dilakukan dengan menggunakan interview guide, hasil wawancara ini diperoleh dari narasumber yang berasal dari pengurus dan anggota MGMP Sosiologi SMA di kabupaten Sleman yang menyangkut tentang gambaran umum tentang sejarah singkat lahirnya MGMP Sosiologi disertai visi dan misi MGMP Sosiologi. Sedangkan metode dokumetasi dilakukan untuk memperoleh sumber-sumber tertulis berupa rencana atau program-program yang akan dilakukan pencarian bukti tertulis mengenai program kerja, daftar anggota MGMP Sosiologi, daftar hadir rapat MGMP Sosiologi serta hasil evaluasi dari lembaga pendidikan yang terkait. Metode kepustakaan digunakan untuk mencari hasil penelitian orang lain yang relevan dan buku-buku penunjang tentang organisasi profesi guru. Teknik yang digunakan adalah teknik purposive sampling digunakan untuk memilih sampel secara acak tapi dapat mewakili informasi tentang peranan MGMP Sosiologi dalam meningkatkan kompetensi profesional guru.

Hasil dari penelitian ini antara lain sebagai berikut : Hasil monitoring dari LPMP yang terdiri dari empat kriteria yang dapat dijabarkan sebanyak 20 point namun, dari 20 poin tersebut program kerja yang menunjukkan usaha dalam meningkatkan kompetensi profesional hanya 3 poin atau $15 \%$ saja. Selain itu dari empat kriteria pokok evaluasi MGMP Sosiologi hanya mampu memenuhi tiga kriteria saja yaitu sekitar $75 \%$. Dalam Peraturan Menteri Pendidikan Nasional Republik Indonesia terdapat lima kriteria yang harus dimiliki seorang guru sosiologi namun, belum semua guru sosiologi di kabupaten Sleman ini dapat menggunakan teknologi informatika dalam KBM, karena latar belakang pendidikan guru sosiologi berbeda menyebabkan perbedaan persepsi dalam penguasaan materi, stuktur, konsep dan pola pikir
\end{abstract}

\footnotetext{
${ }^{1}$ Penulis adalah alumni Program Studi Pendidikan Sosiologi, FISE, Universitas Negeri Yogyakarta
} 
keilmuan mata pelajaran sosiologi. Sehingga peranan MGMP Sosiologi dalam program kerjanya untuk meningkatkan kompetensi profesional guru dikatakan belum terlaksana secara maksimal dan tingkat kompetensi profesional yang dimiliki guru sosiologi saat ini belum sesuai dengan Peraturan Menteri Pendidikan Nasional dan UUGD No.14/2005.

Kata Kunci: Kompetensi, MGMP, Evaluasi

\section{A. Pendahuluan}

Pendidikan adalah suatu proses di mana suatu bangsa mempersiapkan generasi mudanya untuk menjalankan kehidupan dan untuk memenuhi tujuan hidup secara efektif dan efisien. Secara garis besar, pencapaian pendidikan nasional masih jauh dari harapan, apalagi untuk mampu bersaing secara kompetitif dengan perkembangan pendidikan pada tingkat global. Sekolah membutuhkan guru atau pendidik yang mempunyai kemampuan atau kompetensi mengajar dan mendidik secara inovatif, kreatif, manusiawi, cukup waktu untuk menekuni tugas profesionalnya, dapat menjaga wibawanya di mata peserta didik dan masyarakat (menjaga "professional conscience") serta mampu meningkatkan mutu pendidikan (Sumitro dkk., 2005:5261).

Profesi seorang guru atau pendidik sampai saat ini masih menjadi perbincangan oleh sebagian besar dari kalangan pakar pendidikan ataupun bukan pakar pendidikan. Bahkan dalam beberapa waktu yang lalu masyarakat cenderung mencemooh atau menuding seorang guru tidak kompeten, tidak berkualitas dan sebagainya. Hal ini diakibatkan jika putra atau putri mereka tidak mampu menyelesaikan persoalan yang mereka hadapi secara sendiri ataupun tidak sesuai dengan keinginannya.

Sikap dan perilaku masyarakat tersebut bukan tanpa alasan, hal ini terjadi dikarenakan terdapat beberapa oknum guru yang melanggar atau menyimpang dari kode etik guru. Sekecil apapun guru melakukan suatu kesalahan pasti mengundang reaksi yang tajam dari berbagai masyarakat. Hal ini menjadikan bahwa seorang guru seyogyanya dapat menjadi anutan atau panutan oleh masyarakat di sekitarnya. Lebih dari sekedar panutan, guru sampai saat ini masih dianggap eksis, sebab kapanpun posisi atau peran seorang guru tidak dapat digantikan walapun digantikan oleh alat yang canggih sekalipun. Faktor inilah yang mendorong semua pihak untuk berusaha meningkatkan kualitas atau kompetensi seorang guru.

Seorang guru yang sesuai dengan UU RI No 14/2005 tentang Guru dan Dosen menyatakan bahwa seorang guru yang profesional harus mempunyai empat kompetensi, meliputi: kompetensi kepribadian, kompetensi paedagogik, kompetensi profesional dan kompetensi sosial. Kompetensi kepribadian yaitu seorang guru 
harus memiliki pribadi yang mantap dan stabil, dewasa, arif, berwibawa dan berakhlak mulia, Kompetensi paedagogik adalah kemampuan seorang guru untuk berusaha memahami siswanya, mampu melaksanakan serta mengevaluasi proses pembelajaran yang telah dilakukan, serta mampu melakukan pengembangan sikap percaya diri bagi siswanya. Kompetensi profesional adalah kemampuan seorang guru dalam menguasai keilmuan sesuai bidang studi dan langkah kritis, pendalaman isi bidang studi. Sedangkan kompetensi sosial adalah kemampuan seorang guru untuk meningkatkan sikap empati dan sikap peduli pada lingkungan sekitar. Seorang guru harus memiliki salah satu faktor yang cukup penting antara lain yaitu kompetensi profesional. Dari permasalahan pendidikan yang terdapat di Indonesia tersebut, peneliti tertarik dalam topik profesionalisme guru dan tenaga kependidikan yang belum memadai khususnya guru mata pelajaran Sosiologi SMA di Sleman. Mata pelajaran Sosiologi merupakan salah satu ilmu sosial yang belum lama ada di tingkat pendidikan, sehingga tidak heran jikalau guru pengampu mata pelajaran Sosiologi bukan berlatar belakang dari pendidikan Sosiologi.

Selain itu perkembangan

ilmu Sosiologi dan untuk meningkatkan kualitas profesional dari guru Sosiologi didukung oleh suatu organisasi profesi guru
Sosiologi yaitu Musyawarah Guru Mata Pelajaran (MGMP) Sosiologi. Organisasi profesi guru Sosiologi merupakan organisasi berbadan hukum yang dimaksudkan untuk melakukan suatu usaha untuk mengembangkan ilmu Sosiologi itu sendiri.

Hal itu, sama halnya dengan UU RI No. 14/2005 tentang Guru dan Dosen pada pasal 41 menyatakan bahwa organisasi profesi mempunyai fungsi untuk memajukan profesi, meningkatkan kompetensi, meningkatkan karier, meningkatkan

wawasan kependidikan, melakukan perlindungan profesi, meningkatkan kesejahteraan para guru dan pengabdian guru kepada masyarakat. Setiap guru wajib untuk menjadi anggota organisasi profesi. Sehingga suatu organisasi profesi guru yaitu MGMP memang dibutuhkan untuk meningkatkan kualitas kinerja guru; khususnya MGMP Sosiologi dibentuk agar dapat meningkatkan kualitas kerja dan sikap profesional guru-guru pengampu mata pelajaran Sosiologi.

Berdasarkan penyataan tersebut, maka perlu dilaksanakan suatu penelitian terhadap peranan MGMP Sosiologi terhadap peningkatan kompetensi profesional guru mata pelajaran Sosiologi terutama di guru mata pelajaran Sosiologi SMA di Sleman, MGMP Sosiologi sangat berperan untuk semakin meningkatkan kualitas guru mata pelajaran sosiologi. Mutu dan efektifitas pembelajaran Sosiologi di sekolah serta ketepatan 
materi-materi pokok yang akan diajarkan kepada siswa. Maka, untuk mengetahui peranan dan pengaruh MGMP Sosiologi diminati dan disenangi untuk siswa sehingga ilmu Sosiologi dapat mengalami perkembangan yang baik.

Tujuan penelitian ini adalah: 1) untuk mengetahui perkembangan kompetensi keprofesional guru mata pelajaran Sosiologi SMA di Sleman, 2) untuk mengetahui peranan MGMP (Musyawarah Guru Mata Pelajaran) Sosiologi dalam peningkatan kompetensi profesional guru mata pelajaran Sosiologi SMA di Sleman.

\section{B. Kajian Teori}

\section{Kajian Teori tentang Peranan}

Peranan (role) merupakan aspek yang dinamis dari kedudukan (status). Apabila seseorang melaksanakan hak dan kewajiban sesuai dengan kedudukannya maka, orang tersebut telah menjalankan peranan (Soerjono Soekanto, 1998: 220). Hubungan-hubungan sosial yang ada dalam masyarakat merupakan hubungan antara peranan-peranan individu-individu dalam masyarakat. Perananperanan tersebut diatur oleh normanorma yang berlaku dalam masyarakat. Peranan yang melekat pada diri seseorang, harus dibedakan dengan posisi atau tempatnya dalam pergaulan masyarakat. Posisi atau tempat seseorang dalam masyarakat (yaitu social-position) merupakan unsur yang statis yang menunjukkan tempat individu dalam organisasi masyarakat (Soerjono Seokanto, 1987:221). Di mana peranan merujuk pada fungsi penyesuaian diri serta sebagai suatu proses jika seseorang menduduku suatu tempat atau posisi dalam masyarakat untuk menjalankan suatu perannya. Untuk itu peranan sangat diperlukan seseorang dalam melakukan hubungan sosial dengan lingkungannya.

Dalam peranan mencakup paling sedikit 3 hal yaitu: a) peranan itu terdiri dari norma-norma yang dihubungkan dengan posisi atau tempat seseorang di dalam masyarakat, b) peranan adalah suatu hal yang mampu dilakukan seseorang sebagai bagian dari organisasi (masyarakat), c) peranan merupakan perikelakuan seorang individu yang penting bagi struktur sosial masyarakat. dalam menjalankan (Soerjono Soekanto, 1987:221).

$\begin{array}{lr}\text { Seseorang } & \text { dalam } \\ \text { menjalankan peranan, oleh }\end{array}$ masyarakat diberikan tempat atau fasilitas yaitu berupa lembagalembaga kemasyarakatan. Oleh karena itu, di dalam pergaulan sehari-hari biasanya seorang individu selalu mempunyai hubungan dengan pihak-pihak lain sebagai rekan untuk menjalankan peranannya tersebut.

Dari berbagai uraian mengenai peranan tersebut di atas, peranan dalam MGMP Sosiologi sangat dibutuhkan seorang guru dalam menjalankan kewajibannya sebagai pendidik. Sangat dirasa perlu seorang guru dapat menjadi bagian dari organisasi profesi guru yaitu MGMP Sosiologi. Peranan yang dapat dilakuakn oleh MGMP Sosiologi bertujuan agar dalam 
mengerjakan dan melaksanakan tugas atau kewajiban sebagai seorang guru sosiologi dapat berjalan sesuai dengan fungsinya. MGMP Sosiologi mempunyai aturan yang mengikat sebagai mana organisasi profesi guru yang lainnya yaitu seorang guru dibatasi oleh kode etik guru agar perikelakuan guru dapat dijadikan contoh dan teladan para siswanya sebagai mana telah tertuang dalam UndangUndang Guru dan Dosen No.14 Tahun 2005.

Dalam MGMP Sosiologi di Kabupaten Sleman ini terdiri dari kumpulan-kumpulan guru mata pelajaran Sosiologi yang berasal dari SMA-SMA Negeri atau Swasta di Kabupaten Sleman pada khususnya. Hubungan-hubungan kerja sama atau interaksi yang terjalin antar anggota MGMP Sosiologi yaitu guru sosiologi ini tercermin dalam penyusunan program kerja organisasi, program kerja guru secara pribadi (administrasi guru), bahan ajar, media pembelajaran, atau penilaian yang akan diterapkan. Jadi, peranan MGMP Sosiologi dalam meningkatkan kompetensi guru SMA di Kabupaten Sleman ini sangat perlu agar tugas, kewajiban seorang guru dapat dijalankan dengan baik sesuai ketentuan yang terdapat dalam Undang-Undang Guru dan Dosen No.14 Tahun 2005.

\section{Kajian Teori tentang Kompetensi Profesional Guru Sosiologi}

Istilah kompetensi berasal dari bahasa Inggris yaitu "competence meansfitness or ability" yang berarti kemampuan atau kecakapan seseorang. Kemampuan melaksanakan sesuatu yang diperolehnya melalui pendidikan ataupun latihan. Dalam hubungannya dengan tenaga professional kependidikan, kompetensi menunjuk pada perbuatan yang bersifat rasional dan memenuhi spesifikasi tertentu di dalam melaksanakan tugasnya di bidang pendidikan (Sardiman AM.M.Pd., 1986:68).

Kompetensi guru sendiri cukup beragam dan berperan dalam perkembangan guru. Hal ini sebagai upaya untuk memajukan dan mengembangkan kemampuan dan kualitas profesi guru itu sendiri. Seorang guru yang sesuai dengan UU RI No. 14/2005 tentang Guru dan Dosen menyatakan bahwa seorang guru yang profesional harus mempunyai empat kompetensi profesional yang paling penting, meliputi: kompetensi kepribadian, kompetensi paedagogik, kompetensi profesional dan kompetensi sosial. Guru adalah seorang pendidik profesional dengan tugas utama yaitu mendidik, membimbing, mengarahkan, melatih, menilai dan mengevaluasi peserta didik pada pendidikan anak usia dini baik jalur pendidikan formal, pendidikan dasar dan pendidikan menengah. 
Kompetensi kepribadian yaitu seorang guru harus memiliki kepribadian mantap dan stabil, dewasa, arif, berwibawa, berakhlaq mulia. Kompetensi paedagogik merupakan kemampuan seorang guru untuk memahami siswa, mampu melakukan perancangan, pelaksanaan dan mengevaluasi proses pembelajaran, serta mampu melakukan pengembangan sikap percaya diri bagi siswa. Kompetensi profesional yaitu seorang guru harus menguasai keilmuan sesuai bidang studi dan langkah kritis, pendalaman isi bidang studi. Kompetensi sosial merupakan kemampuan seorang guru untuk meningkatkan sikap empati (UU RI No. 14/2005 tentang Guru dan Dosen).

Namun, dari keempat kompetensi yang harus dimiliki seorang guru di atas, penelitian ini lebih dititik beratkan pada segi kompetensi profesional seorang guru. Terutama pada guru-guru pengampu mata pelajaran Sosiologi SMA di kabupaten Sleman ini lebih banyak dipegang atau dikelola oleh guru-guru yang tidak berlatar belakang sebagai guru Sosiologi. Adapun ciri-ciri dan syarat sebagai pekerja profesional yaitu :

a. Lebih mementingkan pelayanan kemanusiaan yang ideal.

b. Memiliki spesialisasi ilmu pengetahuan yang mendukung keahliannya.

c. Mempunyai kualifikasi tertentu untuk mengetahui perkembangan dalam keahliannya.

d. Memiliki kode etik. e. Mempunyai daya intelektual tinggi.

f. Membentuk organisasi profesi.

g. Melakukan perkembangan dalam keahliannya.

h. Memandang profesi sebagai karir hidup dan memandang keanggotaan profesi sebagai hal yang permanen (UU RI No. 14/2005 tentang Guru dan Dosen).

Profesi pada hakekatnya adalah suatu pekerjaan yang membutuhkan pengetahuan dan keterampilan yang berkualifikasi tinggi dalam melayani atau mengabdi kepentingan umum untuk mencapai kesejahteraan manusia. Seorang guru profesional akan selalu melakukan atau memberikan pelayanan atau pengabdian di bidang pendidikan untuk menyampaikan ilmu pengetahuan kepada siswa dan mempunyai sikap kepribadian yang luhur yang ditandai oleh normanorma atau kode etik guru. Guru profesional adalah orang yang memiliki kemampuan atau keahlian khusus di bidangnya pada bidang keguruan sehingga ia dapat melakukan tugas dan fungsinya secara tepat. Dengan kata lain, guru professional adalah orang yang terdidik dan terlatih dengan baik dan memiliki kemampuan yang kaya di bidangnya (Drs. Moh. Uzer Usman, 2006:15).

Terlatih dan terdidik dimaksudkan adalah bukan hanya memperoleh pendidikan formal tetapi juga harus menguasai berbagai strategi atau teknik di dalam kegiatan belajar mengajar 
serta menguasai landasan-landasan kependidikan seperti yang tercantum dalam kompetensi guru profesional yang mempunyai syarat-syarat antara lain :

a. Mempunyai keterampilan berdasarkan konsep dan teori ilmu

b. pengetahuan secara mendalam,

c. Memiliki keahlian khusus di bidangnya,

d. Adanya tingkat pendidikan keguruan yang memadai,

e. Adanya kepekaan terhadap masyarakat,

f. Terdapat perkembangan yang sejalan dengan dinamika kehidupan (Drs. Moh. Uzer Usman, 2006:15).

Profesi guru ditempuh melalui jenjang pendidikan pre service education seperti pendidikan di Perguruan Tinggi khusus keguruan. Kompetensi profesional seorang guru meliputi :

a. Menguasai landasan kependidikan

b. Menguasai bahan pengajaran

c. Menyusun program pengajaran

d. Melaksanakan program pengajaran

e. Menilai hasil dan proses belajar mengajar yang telah dilaksanakan (Drs.Moh. Uzer Usman, 2006:19).

Dari beberapa definisi tersebut, guru tidak hanya sebatas orang yang telah dan mampu menyelesaikan pendidikan kegururan dan mengajar di sekolah, akan tetapi mereka juga mengajar pada lembaga-lembaga pendidikan non formal. Oleh karena tu, seorang guru sosiologi adalah seorang yang mempunyai kemampuan dan pengetahuan yang luas tentang kebudayaan dan dituntut untuk mempunyai pengetahuan yang luas dan dalam pada aspek sosial-masyarakat. Sewajarnya bahwa fungsi guru sosiologi adalah mampu menyampaikan fakta yang benar sehingga siswa dapat berfikir realistis.

Guru sosiologi yang profesional merupakan seorang guru yang mempunyai latar belakang sebagai lulusan dari pendidikan Sosiologi, mempunyai sertifikat profesional sebagai guru sosiologi serta mampu melaksanakan tugas dan fungsi sebagai guru sosiologi secara profesional yang memang sesuai dengan bidangnya. Sehingga guru sosiologi yang profesional adalah seseorang yang memiliki kemampuan dan keahlian khusus di bidang mata pelajaran sosiologi serta mampu melaksanakan tugas dan fungsi (hak dan kewajiban) sebagai guru sosiologi yang profesional dan mampu melakukan evaluasi terhadap kegiatan belajar mengajar yang telah dilaksanakan.

\section{Kajian Teori tentang Musyawarah Guru Mata Pelajaran (MGMP) Sosiologi}

Suatu kelompok sosial atau social-group cenderung tidak merupakan kelompok-kelompok yang statis, akan tetapi selalu 
berkembang serta mengalami perubahan-perubahan baik dalam aktifitas maupun bentuknya. Kelompok sosial atau social-group tadi dapat dapat menambahkan alat-alat perlengkapan untuk dapat melaksanakan fungsi-fungsinya yang baru di dalam rangka perubahan-perubahan yang dialaminya atau bahkan sebaliknya dapat mempersempit ruang lingkupnya. Sesuatu aspek yang menarik dari kelompok sosial atau social-group tersebut adalah bagaimana cara mengendalikan anggota-anggotanya (Soerjono Soekanto,1987:104).

Dalam suatu kelompok sosial atau social-group diperlukan beberapa persyaratan tertentu, antara lain :

a. Setiap anggota kelompok tersebut harus sadar bahwa sebagian dari kelompok yang bersangkutan,

b. ada hubungan timbal-balik antara anggota yang satu dengan anggota lainnya, dalam kelompok itu,

c. ada suatu faktor yang dimilik bersama oleh anggotaanggota kelompok itu, sehingga hubungan antar mereka bertambah erat. Faktor tadi dapat merupakan nasib yang sama, kepentingan yang sama, tujuan yang sama, ideologi politik yang sama dan lainlain. Tentunya faktor mempunyai musuh bersama misalnya, dapat pula menjadi faktor pengikat atau pemersatu. d. berstuktur, berkaidah dan mempunyai pola perilaku (Soerjono Soekanto, 1987:103).

Suatu kelompok sosial atau social-group ini biasanya anggotaanggotanya saling kenal-mengenal (face-to-face group-ings), selain itu kelompok sosial atau social-group dapat terbentuk atas ukuran kepentingan dan wilayah serta anggota-anggotanya secara sadar akan kepentingan bersama tersebut (Soerjono Soekanto, 1987:105).

Kelompok sosial atau socialgroup dalam penelitian ini dicontohkan dalam organisasi profesi guru Sosiologi yaitu Musyawarah Guru Mata Pelajaran (MGMP) Sosiologi. Musyawarah Guru Mata Pelajaran (MGMP) Sosiologi merupakan suatu kelompok formal (formal-group). Di mana kelompok formal (formalgroup) merupakan suatu kelompokkelompok yang mempunyai peraturan yang tegas dan dengan sengaja diciptakan oleh anggotaanggotanya untuk mengatur hubungan antara anggotaanggotanya, misalnya peraturanperaturan untuk memilih seorang ketua, pemungutan iuran dan sebagainya. Anggota-anggotanya mempunyai kedudukan tertentu sebagaimana telah diatur hal mana sekaligus berarti suatu pembatasan tugas dan wewenang baginya. Kelompok formal (formal-group) sering juga disebut dengan association. 
C. Pembahasan

1. Pengertian Musyawarah Guru Mata Pelajaran (MGMP) Sosiologi

Musyawarah Guru Mata

Pelajaran (MGMP) Sosiologi adalah suatu organisasi yang terdiri dari orang-orang yang mempunyai satu profesi yang sama, profesinya sebagai guru khususnya guru sosiologi tingkat Sekolah Menengah Atas (SMA) yang berada di wilayah. MGMP Sosiologi adalah salah satu organisasi profesional guru yang berada di wilayah kabupaten Sleman ini, guru-guru sosiologi berpartisipasi dalam MGMP Sosiologi karena pada dasarnya mereka telah melakukan suatu interaksi. Guru-guru sosiologi yang terjaring dalam satu wadah organisasi yaitu MGMP Sosiologi terbentuk atas ukuran kepentingan yang sama. MGMP Sosiologi terbentuk atas ukuran kepentingan dan kebutuhan yang sama dalam hal mata pelajaran sosiologi. MGMP Sosiologi terbentuk secara resmi dan juga atas persetujuan dari kesepakatan Musyawarah Kelompok Kepala Sekolah (MKKS) yang juga MGMP Sosiologi adalah suatu kelompok yang formal karena di bawah pengetahuan dan perlindungan oleh Dinas Pendidikan dan Pemerintah.

MGMP Sosiologi dibentuk karena dipandang sangat diperlukan dan dibutuhkan oleh guru-guru sosiologi di kabupaten Sleman sebab dengan adanya MGMP Sosiologi yang adalah organisasi satu profesi ini dapat membantu guru-guru sosiologi dalam menemukan permasalahan yang dihadapi dan sehingga mampu untuk memecahkan atau memberikan solusi dari permasalahan yang selama ini dihadapi. Masalah yang dihadapi selama belum terbentuk MGMP Sosiologi antara lain meliputi prestasi belajar siswa yang kurang, kesulitan guru dalam mengajar, kesulitan dalam membimbing siswa yang memiliki perbedaan karakteristik ataupun kesulitan dalam mengerjakan administrasi. Selama ini setiap menemukan masalah-masalah tersebut yang ada hanya dibiarkan saja sehingga tidak dapat terselesaikan dengan benar dan tuntas. Akan tetapi setelah terbentuknya MGMP Sosiologi ini dapat membantu terselesaikannnya masalah atau kendala tersebut, di mana pemecahan masalah tersebut dilakukan secara musyawarah bersama. Selain itu, MGMP Sosiologi juga bermanfaat untuk memajukan profesi, meningkatkan kompetensi guru, meningkatkan wawasan kependidikan, meningkatkan pengabdian guru sosiologi ini kepada siswa dan untuk masyarakat.

\section{Hak dan Kewajiban Anggota MGMP Sosiologi}

Setiap kegiatan di dalam organisasi apapun itu tidak terkecuali pada MGMP Sosiologi, setiap anggotanya mempunyai kewajiban yang harus dilakukan dan mempunyai hak yang harus mereka terima. Guru-guru sosiologi yang menjadi anggota MGMP 
Sosiologi ini mempunyai beberapa hak antara lain :

a. Hak untuk menerima imbas dari guru sosiologi yang lain untuk dapat berpartisipasi dalam mata pelajaran sosiologi.

b. Hak untuk bisa menerima dalam porsi yang sama atau kedudukan yang sama sehingga mempunyai kemampuan yang sama dalam mengampu mata pelajaran sosiologi.

Selain itu anggota juga mempunyai kewajiban yang berupa:

a. Kewajiban untuk mengimbaskan atau menyebarluaskan informasi yang diterimanya dalam pelatihan kepada guru sosiologi yang lainnya.

b. Kewajiban untuk menyusun dan mengembangkan kurikulum dan mengerjakan administrasi sebagai guru mata pelajaran sosiologi.

3. Peranan Musyawarah Guru Mata Pelajaran (MGMP) Sosiologi
Peranan MGMP Sosiologi dalam meningkatkan kompetensi profesional guru dapat dilihat dari program kerja. Program kerja MGMP Sosiologi dibuat dan direncanakan dengan jalan musyawarah bersama-sama antara pengurus dan anggota MGMP Sosiologi di awal tahun ajaran baru. Program kegiatan dari MGMP Sosiologi ini terbagi menjadi 3, program tersebut antara lain adalah:

a. Program jangka pendek

b. Program jangka panjang

c. Program insidental

Program jangka pendek adalah program kerja yang dalam waktu 1 semester wajib disusun oleh guru sosiologi antara lain berkaitan dengan administrasi guru yaitu silabus, Rencana Pelaksanaa Pembelajaran (RPP), sistem penilaian atau evaluasi hasil pembelajaran dan kegiatan rapat atauseminar. Berikut adalah susunan jadwal kegiatan yang diprogramkan oleh MGMP Sosiologi yang dapat dikatakan sebagai penunjang untuk meningkatkan kompetensi guru sosiologi, yaitu :

Tabel 1.

Jadwal Kegiatan MGMP Sosiologi

\begin{tabular}{|l|l|l|}
\hline \multicolumn{1}{|c|}{ Hari/Tanggal } & \multicolumn{1}{|c|}{ Materi } & \multicolumn{1}{|c|}{ Narasumber } \\
\hline Sabtu/21 Juni 2008 & $\begin{array}{l}\text { Pengembangan } \\
\text { Silabus }\end{array}$ & $\begin{array}{l}\text { Drs. Sutanto/ } \\
\text { Sri Saptina, S.Pd. }\end{array}$ \\
\cline { 1 - 2 } Sabtu/12 Juli 2008 & $\begin{array}{l}\text { Pengembangan } \\
\text { Silabus }\end{array}$ & \\
\cline { 1 - 2 } Sabtu/26 Juli 2008 & $\begin{array}{l}\text { Pengembangan } \\
\text { Silabus }\end{array}$ & $\begin{array}{l}\text { Dwi Nugraha, S.Pd./ } \\
\text { Drs. Aris Sutardi }\end{array}$ \\
\cline { 1 - 2 } Sabtu/9 Agustus 2008 & $\begin{array}{l}\text { Pengembangan } \\
\text { Media }\end{array}$ & Pengembangan \\
\hline
\end{tabular}


Peranan MGMP Sosiologi

\begin{tabular}{|c|c|c|}
\hline & Media & \\
\hline $\begin{array}{ll}\text { Sabtu/6 September } \\
2008\end{array}$ & $\begin{array}{l}\text { Pengembangan } \\
\text { Media }\end{array}$ & \\
\hline $\begin{array}{ll}\text { Sabtu/20 September } \\
2008\end{array}$ & $\begin{array}{l}\text { Pengembangan } \\
\text { Bahan Ajar }\end{array}$ & \multirow{3}{*}{ LPMP } \\
\hline Sabtu/11 Oktober 2008 & $\begin{array}{l}\text { Pengembangan } \\
\text { Bahan Ajar }\end{array}$ & \\
\hline Sabtu/18 Oktober 2008 & $\begin{array}{l}\text { Pengembangan } \\
\text { Bahan Ajar }\end{array}$ & \\
\hline Sabtu. 1 November 2008 & $\begin{array}{l}\text { Pengembangan } \\
\text { Profesi Guru }\end{array}$ & $\begin{array}{l}\text { Drs. Purwanto } \\
\text { SU.M.Fil (UGM) }\end{array}$ \\
\hline Sabtu, 8 November 2008 & $\begin{array}{l}\text { Pengembangan } \\
\text { Profesi Guru }\end{array}$ & $\begin{array}{l}\text { Dra.AG. Suhartati } \\
\text { Dwi Nugraha, S.Pd./ } \\
\text { Sri Saptina, S.Pd. }\end{array}$ \\
\hline Sabtu, 8 November 2008 & $\begin{array}{l}\text { Pengembangan } \\
\text { Profesi Guru }\end{array}$ & $\begin{array}{l}\text { Dra.AG. Suhartati } \\
\text { Dwi Nugraha, S.Pd./ } \\
\text { Sri Saptina, S.Pd. }\end{array}$ \\
\hline $\begin{array}{l}\text { Sabtu, } 15 \text { November } \\
2008\end{array}$ & $\begin{array}{l}\text { Penelitian Tindakan } \\
\text { Kelas }\end{array}$ & LPMP \\
\hline $\begin{array}{l}\text { Sabtu, } 22 \text { November } \\
2008\end{array}$ & $\begin{array}{l}\text { Penelitian Tindakan } \\
\text { Kelas }\end{array}$ & $\begin{array}{l}\text { Dra. Purwondari/ } \\
\text { Drs. Sutanto/ Sugeng } \\
\text { R/ } \\
\text { Abd. Rifki/ } \\
\text { Dra. Rosmeri }\end{array}$ \\
\hline Sabtu, 6 Desember 2008 & $\begin{array}{l}\text { Pengembangan Alat } \\
\text { Peraga }\end{array}$ & $\begin{array}{l}\text { Novi / } \\
\text { Wardayati S.Ag. }\end{array}$ \\
\hline
\end{tabular}

Dari program kegiatan yang telah dilaksanakan oleh MGMP Sosiologi di atas merupakan usaha atau peranan MGMP Sosiologi dalam meningkatkan kompetensi profesional guru sosiologi akan tetapi jadwal kegiatan tersebut belum seluruhnya dapat memenuhi kompetensi profesional yang ditetapkan oleh Menteri Pendidikan Nasional. Materi pengembangan silabus merupakan salah satu materi yang harus dilakukan guru dalam menguasai materi serta memahami SK, KD dan tujuan mata pelajaran yang diampunya dapat ditransfer kepada siswa selain itu juga materi yang ada dapat dikembangkan oleh guru sosiologi. Materi pengembangan profesi guru sangat diperlukan karena perbedaan latar belakang pendidikan guru sosiologi yang bermacam-macam tentu sangat mempengaruhi cara pandang guru dalam menyampaikan, selain itu materi pengembangan profesi guru dilakukan untuk menyamakan persepsi guru sosiologi dalam hal bahan ajar yana akan diberikan 
untuk siswa. Materi Penelitian Tindakan Kelas (PTK) digunakan agar guru dapat melakukan refeksi terhadap kinerjanya sendiri dan berusaha untuk meningkatkan keprofesionalannya. Sedangkan materi pengembangan media dan pengembangan alat peraga difungsikan untuk guru agar mampu menguasai dan memanfaatkan teknologi informatika dalam mengajarnya.

MGMP

Sosiologi

mengundang narasumber dari lembaga pendidikan lain jika pihak MGMP Sosiologi sudah merasa kesulitan akan kegiatan atau program yang direncanakan. MGMP Sosiologi mengundang narasumber dari UGM yaitu Drs. Purwanto SU.M.Fil pada tahun 2008 sebanyak satu kali saja. Sedangkan narasumber dari LPMP dilakukan sebanyak dua kali yaitu pada materi pengembangan bahan ajar dan penelitian tindakan kelas. Materi yang terdapat dalam jadwal kegiatan MGMP Sosiologi tersebut di atas adalah upaya MGMP Sosiologi untuk meningkatkan kompetensi profesional guru. Adapun materi yang berkaitan dengan upaya meningkatkan kompetensi profesional guru antara lain pengembangan silabus, pengembangan media serta pengembangan bahan ajar, di mana ketiga hal tersebut telah dapat menunjukkan beberapa kriteria kompetensi profesional yang tertuang dalam UUGD No.14/2005. Materi penelitian tindakan kelas juga diperlukan untuk mendukung kompetensi profesional guru dalam memberikan bahan ajar selama
PBM. Selain itu agar para guru dan siswa dapat melaksanakan PBM yang menarik tentu saja diperlukan materi dengan tema pengembangan alat peraga, penggunaan media atau alat peraga dalam PBM juga mencerminkan penguasaan di bidang teknologi informatika yang mana dibutuhkan guru dalam mengajar di kelas dan sesuai dengan apa yang diperlukan dalam mendukung kompetensi profesional guru sosiologi.

Sedangkan program jangka panjang adalah program yang dilakukan dalam kurun waktu 1 tahun $1 \mathrm{X}$ dalam rangka untuk mengembangkan teori dengan praktek di lapangan, kegiatan tersebut adalah studi lapangan. Studi lapangan yang dilaksanakan dalam program jangka panjang ini adalah untuk mengembangkan materi sosiologi tentang multikultural. Namun, dalam tahun ini studi lapangan sebagai program jangka panjang ini tidak dilakukan karena secara pribadi para anggota lebih memilih untuk membagikan uang subsidi untuk keperluan guru pribadi daripada melaksanakan studi lapangan ini bersama-sama guru lain.

Kemudian dalam melaksanakan dan merencanakan berbagai macam program kerja dari MGMP Sosiologi ini dibutuhkan pula dukungan materiil elain dukungan moril. Bantuan yang ada diberikan kepada MGMP Sosiologi iu berasal dari pihak Pemerintah, LPMP dan dari anggota sendiri yang berasal dari dana iuran. Bantuan-bantuan tersebut sangat membantu dalam melaksanakan 
program kerja dari MGMP Sosiologi di kabupaten Sleman ini, baik itu digunakan pada program jangka pendek, jangka panjang ataupun program insidental yang bermanfaat demi memajukan MGMP Sosiologi, mata pelajaran sosiologi dan para guru sosiologi di Sleman ini.

Namun, selama ini dalam mengadakan rapat MGMP Sosiologi mendapat berbagai hambatan. Selain menggunakan sekolah untuk rapat atau pelatihan bagi guru sosiologi juga digunakan tempat lain sebagai sarana untuk kejenuhan. Ada pula hambatan yang lain yaitu ketidakhadiran guru-guru karena terhalangi oleh jarak tempuh yang jauh disebabkan wilayah kabupaten Sleman ini meliputi Sleman Barat, Sleman Timur, Sleman Utara dan Sleman Selatan yang terdiri dari 17 kecamatan sehingga guru-guru tersebut merasakan kejauhan dan kerepotan jika harus hadir dalam rapat tersebut. Dengan beberapa hambatan itu maka, MGMP Sosiologi memberikan sebuah terobosan untuk mengatasi kendala tersebut. Jika guru-guru merasakan Sedangkan untuk mengatasi jarak tempuh yang jauh ini, MGMP Sosiologi melakukan sistem rolling atau berpindah-pindah tempat rapat, kadang berada di wilayah utara, selatan, barat atau timur. Sehingga para anggota tidak merasa jenuh dan sungkan apalagi kerepotan untuk mengikuti kegiatan rapat MGMP Sosiologi.
Dari hambatan tersebut di atas ternyata masih terdapat pula kendala yang lain dalam rapat untuk proses penyusunan program MGMP Sosiologi. Kendala itu adalah :

a. Kemampuan para anggota yang belum cukup jauh menjangkau mata pelajaran sosiologi serta dalam hal pengembangan silabus.

b. Terkadang narasumber tidak dapat menghadiri kegiatan tersebut.

c. Dana yang kurang. Meskipun terdapat kendala tersebut MGMP Sosiologi juga melakukan berbagai solusi untuk mengatasinya. Untuk mengatasi hambatan dalam hal kemampuan guru yang kurang menjangkau dalam pengembangan silabus maka mengadakan pelatihan atau seminar yang mengundang narasumber sebagai pemateri seperti dari UGM ataupun LPMP. Akan tetapi jikalau narasumber yang diundang tidak dapat hadir maka, MGMP Sosiologi tetap melaksanakan kegiatan tersebut dengan mengundur jadwal kegiatan tersebut. Pada masalah dana yang kurang, MGMP Sosiologi menerima bantuan dari Pemerintah dalam hal yang berkaitan dengan Block Grant Revitalisasi Program MGMP Sosiologi, pihak LPMP memberikan bantuan dana sebesar Rp. 15.000.000,- dan dari iuran para anggota sebesar Rp. 50.000,- setiap sekolah. Bantuan tersebut dapat digunakan dalam penyusunan dan pelaksanaan program MGMP Sosiologi dan dapat meningkatkan 
kualitas atau kompetensi profesional guru sosiologi.

Lembaga pendidikan yaitu UGM melakukan kerja sama dengan MGMP Sosiologi karena UGM merupakan universitas satu-satunya yang berada di wilayah Yogyakarta yang memiliki jurusan sosiologi karena UNY belum lama memiliki program jurusan sosiologi. Sehingga pihak UGM mampu memberikan pelatihan atau menjadi narasumber dalam kegiatan MGMP Sosiologi untuk meningkatkan kemampuan dan kompetensi guru sosiologi yang ada. Dosen yang menjadi narasumber kegiatan MGMP Sosiologi dari UGM tersebut antara lain bapak Ari Sudjito, mereka memberikan materi pelatihan yang berkaitan dengan sikap seorang guru sosiologi, langkah guru sosiologi agar mampu menjelaskan materi sosiologi di dalam kelas lebih mudah dipahami siswa. Dosen UGM yang lain adalah bapak Purwanto S.U., M.Fil. memberikan materi pelatihan tentang pengembangan profesi guru sosiologi. Pemerintah selain memberikan dana Block Grant Revitalisasi Program MGMP Sosiologi, juga membantu dalam pengembangan bahan ajar yang terdiri dari modul dan pengembangan bahan ajar dengan alat peraga. Kemudian yang berkaitan dengan usaha meningkatkan kualitas dan kompetensi profesional guru sosiologi dalam mengajar di kelas, mengetahui proses pembelajaran yang terjadi dan melihat kekurangan atau kelebihan guru dalam mengajar, MGMP Sosiologi mendapat bimbingan dan dukungan dari LPMP.

Untuk mendukung program MGMP Sosiologi, Sie Pendidikan mempunyai program khusus untuk menangani hal-hal yang berkaitan tentang pendidikan di mata pelajaran sosiologi. Dengan demikian Sie Pendidikan akan membicarakan tentang usaha meningkatkan kompetensi profesional guru sosiologi agar lebih baik dan membahas mengenai bahan ajar mata, media pembelajaran, menyusun soal-soal untuk ujian. Walaupun sifat perekrutan anggota MGMP Sosiologi adalah sukarela yang tidak mewajibkan guru sosiologi menjadi anggota MGMP Sosiologi tetapi tetap menyarankan mereka untuk berusaha meningkatkan kompetensi profesional guru sosiologi. Akan tetapi, ditegaskan oleh ketua MGMP Sosiologi bahwa untuk meningkatkan kompetensi profesional sebagai guru sosiologi tidak selalu dengan menjadi anggota MGMP Sosiologi tetapi dengan mengikuti seminar atau pelatihan yang diselenggarakan oleh MGMP Sosiologi, LPMP ataupun lembaga lainnya.

\section{Tingkat Kompetensi Guru Mata Pelajaran Sosiologi}

Guru-guru sosiologi yang tergabung dalam MGMP Sosiologi di Sleman ini sebanyak 30 orang yang berstatus anggota aktif. Akan tetapi dari 30 orang anggota tersebut hanya diketahui 9 orang saja yang mempunyai latar belakang pendidikan yang mendekati dengan sosiologi, itupun 
bukan berasal dari jurusan pendidikan sosiologi tetapi dari jurusan sosiologi murni, jurusan filsafat dan sosiologi, jurusan pendidikan sosiologi dan antropologi bahkan ada yang berasal dari jurusan yang berbeda jauh dari pendidikan sosiologi seperti dari PKn, Geografi, Sejarah, Administarsi Pendidikan, dan BK. Anggota MGMP Sosiologi berasal dari gabungan guru-guru sosiologi yang berada di wilayah kabupaten Sleman ini. Mata pelajaran sosiologi selama ini diampu oleh guru-guru sosiologi yang bukan dari bidangnya. Bukan berasal dari bidangnya tapi mampu mengajar mata pelajaran sosiologi disebabkan oleh di sekolah tertentu merasa kelebihan tenaga pendidik sehingga guru tersebut dialih tugaskan menjadi guru mata pelajaran sosiologi agar tidak terjadi kekosongan tugas guru di sekolah tersebut. Di Indonesia ini mengadakan mata pelajaran sosiologi akan tetapi lembaga pendidikan yang ada belum mempunyai jurusan sosiologi sehingga belum mampu mencetak lulusan sebagai guru sosiologi. Jikapun ada lulusan guru sosiologi, jumlahnya pun belum mampu mencukupi, janganpun untuk memenuhi jumlah guru sosiologi di Indonesia bahkan di kabupaten Sleman ini masih dirasakan sangat kurang akan guru sosiologi.

$$
\text { Jika di dalam UUGD }
$$

No.14/2005 pasal 10 ayat 1 yang berbunyi bahwa kompetensi guru sebagaimana dimaksud dalam pasal
8 meliputi komptensi pedagogik, kompetensi kepribadian, kompetensi sosial dan kompetensi profesional yang diperoleh melalui pendidik profesi. Akan tetapi, pada kenyataannya mata pelajaran sosiologi diampu oleh guru yang bukan dari bidangnya, hal ini merupakan ketidaksesuaian dengan apa yang telah tertuang pada UUGD tersebut terutama tidak sesuai dengan kompetensi profesional sebagai seorang pendidik. Namun, kita jangan hanya dapat mengkritik akan ketidaksesuaian kompetensi profesional guru sosiologi saat ini antara dengan UUGD yang ada, tetapi kita harus berusah untuk bagaimana menjadikan guru sosiologi yang ada sesuai dengan UUGD yang memiliki kompetensi professional agar terjadi perubahan yang baik. Mata pelajaran sosiologi diampu oleh guru mata pelajaran lain ini diakibatkan karena belum adanya lulusan sebagai guru sosiologi.

Sehingga saat ini guru-guru sosiologi belum dapat dikatakan sesuai dengan UUGD No.14/2005 terutama dalam hal kompetensi profesional. Yang menyebabkan guru sosiologi saat ini masih belum memenuhi kompetensi profesionalnya antara lain, yang pertama yaitu latar belakang pendidikan guru sosiologi saat ini berasal dari berbagai disiplin ilmu karena yang tepat adalah latar belakang pendidikan dari pendidikan sosiologi; kedua, penguasaan materi yang kurang; 
ketiga, sikap canggung dan tidak percaya diri guru dalam mengajar di depan kelas karena dasar ilmu yang dimiliki tidak sesuai dengan mata pelajaran sosiologi; dan keempat, penyampaian bahasa kurang luwes dan lugas dalam menyampaikan materi kepada siswa. Kalau guru yang sudah sejurusan dengan bidang mengajarnya tentu dapat dikatakan lebih tepat tetapi karena latar belakang pendidikan di antara guru-guru mata pelajaran sosiologi itulah yang menyebabkan mereka merasa kurang nikmat dalam posisi sebagai guru sosiologi. Untuk itu diharapkan guru-guru mata pelajaran harus sesuai dengan bidangnya masing-masing. Sehingga dalam menangani ketidaksesuaian kompetensi profesional tersebut, MGMP Sosiologi bekerja sama dengan Pemerintah atau Dinas Pendidikan untuk mengembalikan guru-guru yang tidak berasal dari bidangnya masing-masing ataupun sebagai solusi bagi guru sosiologi saat ini untuk melanjutkan pendidikan ke jurusan yang sesuai dengan jurusan sosiologi agar dapat dikatakan sebagai tenaga pendidik yang mempunyai kompetensi profesional yang baik.

Hambatan yang ada akibat perbedaan latar belakang pendidikan guru sosiologi yaitu mereka mengalami kesulitan dalam mengajar di kelas. Yang pertama, guru sosiologi tersebut merasa canggung dalam mengajar, yang kedua guru sosiologi merasakan kesulitan dalam menggunakan bahasa karena bahasa dalam maata pelajaran sosiologi itu harus dikembangkan daripada bahasa yang digunakan pada mata pelajaran yang lainnya. Untuk itu MGMP Sosiologi mendorong, mendukung ibu dan bapak guru menjadi guru sosiologi yang baik dengan sistem: satu, tukar pengalaman antar kawan sesama guru sosiologi; kedua dengan cara pihak MGMP Sosiologi dalam pertemuan tertentu menyuruh para anggota secara bergiliran untuk mengisi kegiatan di muka rapat tentang materi pelajaran sosiologi. Pengisian kegiatan oleh guru secara bergilir tersebut digunakan MGMP Sosiologi untuk melakukan evaluasi tentang kelebihan atau kekurangan guru saat mengajar agar menjadi lebih baik. Berikut dapat dilihat pada keanggotaan dalam MGMP Sosiologi bahwa mata pelajaran sosiologi diampu oleh guru yang kebanyakan bukan dari bidangnya khususnya jurusan kependidikan sosiologi.

Berikut ini adalah nama dan latar belakang pendidikan guru sosiologi yang tergabung dalam MGMP Sosiologi di Kabupaten Sleman:

Tabel 2.

Anggota MGMP Sosiologi Kabupaten Sleman

\begin{tabular}{|c|l|l|l|}
\hline No. & \multicolumn{1}{|c|}{ Nama } & Asal Sekolah & $\begin{array}{c}\text { Latar Belakang } \\
\text { Pendidikan }\end{array}$ \\
\hline 1. & Drs. Sutanto & SMA N 1 & Filsafat dan Sosiologi \\
\hline
\end{tabular}


| Peranan MGMP Sosiologi

\begin{tabular}{|c|c|c|c|}
\hline & & Ngemplak & Pendidikan \\
\hline 2. & Drs. Suharyono & SMA N 1 Ngaglik & $\begin{array}{l}\text { Filsafat dan Sosiologi } \\
\text { Pendidikan }\end{array}$ \\
\hline 3. & $\begin{array}{l}\text { Dwi } \quad \text { Nugroho, } \\
\text { S.Pd. }\end{array}$ & SMA N 1 Depok & \begin{tabular}{|lc} 
1. & AP - FIP \\
IKIP YK & Sosiologi \\
2. Sertifikasi) - FPIPS \\
IKIP YK
\end{tabular} \\
\hline 4. & Sri Saptina, S.Pd. & SMA N 2 Sleman & BK - Universitas PGRI \\
\hline 5. & $\begin{array}{ll}\text { Dra. } & \text { Dyah } \\
\text { Istiarmiyati } & \\
\end{array}$ & SMA GAMA & $\begin{array}{l}\text { Geografi (S1) FPIPS } \\
\text { IKIP YK }\end{array}$ \\
\hline 6. & Mariyatun & $\begin{array}{l}\text { SMA Budi Mulia } \\
\text { Minggir }\end{array}$ & $\begin{array}{l}\text { Pendidikan Sejarah IKIP } \\
\text { YK }\end{array}$ \\
\hline 7. & Drs. Fuadi & SMA N 1 Mlati & Geografi \\
\hline 8. & Komarulhadi, Sos. & SMA N 1 Minggir & Sosiologi (UGM) \\
\hline 9. & Drs. Aris Sutardi & SMA N 1 Pakem & $\begin{array}{c}\text { Geografi (S1) FPIPS } \\
\text { IKIP }\end{array}$ \\
\hline 10 & Dra. Muryantinah & SMA Muh Pakem & Sejarah \\
\hline 11. & Wardayati, S.Pd. & MAN Tempel & $\begin{array}{lr}\text { Pendidikan } & \text { Sosiologi } \\
\text { dan } & \\
\text { Antropologi } & \text { FIS } \\
\text { UNNES } & \\
\end{array}$ \\
\hline 12. & Yustina, S.Pd. & $\begin{array}{l}\text { SMA } \\
\text { Cangkringan }\end{array}$ & BK \\
\hline 13. & Drs. Marijo & $\begin{array}{l}\text { MAN } \\
\text { Maguwoharjo }\end{array}$ & PPKn \\
\hline 14. & $\begin{array}{l}\text { Dra. Rosmeri } \\
\text { Purba }\end{array}$ & SMA Prambanan & $\begin{array}{l}\text { Filsafat dan Sosiologi } \\
\text { Pendidikan }\end{array}$ \\
\hline 15. & Anteng Sulistro & SMA N 1 Mlati & PPKn \\
\hline 16. & $\begin{array}{l}\text { Urip Sadewo, } \\
\text { S.Sos. }\end{array}$ & SMA N 1 Depok & \begin{tabular}{|ll} 
1. & Antropologi \\
& UGM \\
2. & Sosiologi FPIPS IKIP \\
& YK
\end{tabular} \\
\hline 17. & Narina Y., S.Pd. & SMA N 2 Ngaglik & Antropologi \\
\hline 18. & FX. Sudarmin & $\begin{array}{l}\text { SMA St. Michael } \\
\text { Mlati }\end{array}$ & FIP PU IKIP SADHAR \\
\hline 19. & Mariyatun, S.Pd. & $\begin{array}{ll}\text { SMA } & \text { Muh } \\
\text { Seyegan } & \\
\end{array}$ & $\begin{array}{l}\text { Pendidikan Sejarah IKIP } \\
\text { YK }\end{array}$ \\
\hline 20. & Drs. Djumanto & SMA N 1 Tempel & AP FIP IKIP YK \\
\hline 21. & $\begin{array}{l}\text { Sugeng Raharjo, } \\
\text { S.Pd. }\end{array}$ & $\begin{array}{l}\text { SMA Sunan } \\
\text { Kalijaga }\end{array}$ & PKn \\
\hline
\end{tabular}




\begin{tabular}{|c|l|l|l|}
\hline 22. & $\begin{array}{l}\text { Dra. Endang } \\
\text { Siswati }\end{array}$ & $\begin{array}{l}\text { SMA Mandala } \\
\text { Bakti }\end{array}$ & $\begin{array}{l}\text { FSP FIP Sarjana Wiyata } \\
\text { Taman Siswa }\end{array}$ \\
\hline 23. & $\begin{array}{l}\text { Dra. C. Dyah } \\
\text { Yuliati }\end{array}$ & SMA Kolombo & $\begin{array}{l}\text { Sosiologi } \\
\text { UNSOED } \\
\text { Akta Mengajar IV }\end{array}$ \\
\hline 24. & Wus Utami, S.Pd. & $\begin{array}{l}\text { SMA Sulaiman/ } \\
\text { MASPA }\end{array}$ & $\begin{array}{l}\text { Filsafat dan Sosiologi } \\
\text { Pendidikan }\end{array}$ \\
\hline 25. & Drs. Abdurifi & $\begin{array}{l}\text { SMA Islam 3 } \\
\text { Sleman }\end{array}$ & $\begin{array}{l}\text { Pendidikan } \\
\text { FPIPS } \\
\text { IKIP }\end{array}$ \\
\hline 26. & Dra. Purwandari \\
\hline 27. & Drs. Marsigit & SMA N 1 Godean & PPKn \\
\hline 28. & $\begin{array}{l}\text { Lusri Wiyatun, } \\
\text { S.Pd. }\end{array}$ & SMA N 1 Kalasan & $\begin{array}{l}\text { Pendidikan Sosial FIP } \\
\text { IKIP YK }\end{array}$ \\
\hline 29. & Kaswadi & $\begin{array}{l}\text { SMA Islam 1 } \\
\text { Sleman }\end{array}$ & PKn \\
\hline 30. & Drs. Slamet Ansori & SMA N 1 Kalasan & KTP UNY \\
\hline
\end{tabular}

Dari 30 orang anggota MGMP Sosiologi yang berstatus aktif dalam MGMP Sosiologi hanya terdapat 9 orang yang memiliki latar belakang pendidikan yang hampir mendekati dengan mata pelajaran yang dipegangnya yaitu mata pelajran sosiologi. Untuk itu dapat diketahui bahwa hanya sekitar $30 \%$ anggota MGMP Sosiologi yang hampir sesuai dengan mata pelajaran yang diampunya. Dari daftar tersebut masih banyak guruguru sosiologi yang berasal dari berbagai disiplin ilmu dan belum sesuai dengan bidangya. Untuk itu guru-guru sosiologi saat ini belum sesuai atau belum tepat dengan UUGD sehingga tingkat kompetensi profesionalnya belum dikatakan baik. Akan tetapi, walaupun kompetensi profesional guru sosiologi saat ini belum baik namun, setelah mengikuti kegiatan organisasi dalam MGMP Sosiologi, mereka juga berantusias untuk selalu mengikuti pelatihanpelatihan atau seminar yang diadakan baik oleh MGMP Sosiologi, LPMP atau Pemerintah atau lembaga lainnya yang mana untuk meningkatkan kualitasnya. Selain itu, terdapat program sertifikasi yang merupakan program Pemerintah agar guru dapat meningkatkan kompetensi profesionalnya dengan memberikan hak sebagai guru yaitu berupa tunjangan kesejahteraan 1x gaji. Dengan sertifikasi tersebut, guruguru sosiologi berlomba-lomba untuk meningkatkan kualitas dengan jalan mengenyam pendidikan yang sesuai jurusan sosiologi. Selain itu, program sertifikasi ini merupakan rangsangan yang baik bagi guru untuk meningkatkan kualitasnya menjadi guru sosiologi yang baik dan benar. 
Peranan MGMP Sosiologi

Akibat latar belakang pendidikan guru sosiologi yang bermacam-macam sangat mempengaruhi KBM di kelas antara lain penggunaan bahasa yang belum baik yang mana mempengaruhi proses penyampaian materi sosiologi kepada siswa. Selain itu, penguasaan materi bahan ajar yang belum maksimal, sikap canggung saat menyampaikan materi sosiologi karena guru tersebut bukan berlatar belakang sebagai guru sosiologi. Dari 30 orang guru sosiologi hanya terdapat 9 orang atau $30 \%$ saja yang mempunyai latar belakang pendidikan hampir sama dengan jurusan sosiologi. Tetapi hal ini juga belum menunjukkan guru sosiologi saat ini mempunyai kompetensi profesional karena latar belakang atau jurusan pendidikan yang mereka ambil tidak sesuai dengan bidang yang diajarnya. Sehingga guru sosiologi saat ini dapat dikatakan belum sesuai dengan kompetensi profesional karena sebagian besar dari guru sosiologi saat ini belum dapat memenuhi kriteria kompetensi profesional seorang guru seperti yang telah tertuang dalam Peraturan Menteri Pendidikan Nasional Republik Indonesia dan UUGD No.14/2005.

\section{Kesimpulan}

Musyawarah Guru Mata Pelajaran (MGMP) Sosiologi adalah suatu organisasi yang terdiri dari orang-orang yang mempunyai satu profesi yang sama, profesinya sebagai guru khususnya guru sosiologi serta mempunyai tujuan dan kepentingan yang sama. MGMP Sosiologi dibentuk karena dipandang sangat diperlukan dan dibutuhkan oleh guru-guru sosiologi di kabupaten Sleman sebab dengan adanya MGMP Sosiologi yang adalah organisasi satu profesi ini dapat membantu guru-guru sosiologi dalam menemukan dan memecahkan masalah yang dihadapi oleh guru sosiologi selama ini. Sifat perekrutan anggota MGMP Sosiologi yang sukarela ini membuktikan bahwa MGMP Sosiologi kurang berperan dalam mengajak guru sosiologi untuk menjadi anggota MGMP Sosiologi di kabupaten Sleman.

MGMP Sosiologi mempunyai 3 program kerja yang penting. Program tersebut adalah program jangka pendek, program jangka panjang dan program insidental. Untuk mengembangkan kualitas dan kompetensi profesional guru sosiologi terdapat dalam program jangka pendek yang mana MGMP Sosiologi membantu guru sosiologi dalam penyusunan administrasinya. Program jangka panjang adalah merupakan studi lapangan yang mengembangkan teori dengan praktek di lapangan. Sedangkan program insidental hanya dilakukan jika dirasa itu diperlukan.

Dari 30 orang anggota yang masih aktif dalam MGMP Sosiologi hanya terdiri 9 orang saja yang mempunyai latar belakang pendidikan yang hampir sesuai dengan jurusan pendidikan 
sosiologi atau sekitar 30\% saja. Selain hal itu, perbedaan latar belakang pendidikan guru-guru sosiologi saat ini mengakibatkan sikap canggung guru dalam mengajar di kelas, penggunaan bahasa yang belum tepat, kurangnya penguasaan materi bahan ajar merupakan kompetensi profesional yang dimiliki guru sosiologi tidak sesuai. Dari lima hal yang terdapat dalam kompetensi profesional tersebut di atas, saat ini belum semua guru-guru sosiologi mampu melaksanakan hal tersebut dikarenakan faktor utamanya yaitu karena perbedaan latar belakang pendidikan guru sosiologi menyebabkan terjadinya perbedaan pola pikir dan perbedaan persepsi mata pelajaran sosiologi. Selain itu belum semua guru sosiologi mampu menggunakan media atau teknologi informatika sebagai alat untuk mempermudah dalam KBM.

\section{Daftar Pustaka}

Moh. Uzer Usman. 2006. Menjadi Guru Profesional. Bandung: Remaja Rosdakarya

Sardiman AM.M.Pd.. 1986. Interaksi dan Motivasi Belajar Mengajar. Jakarta: Raja Grafindo Persada.

Soerjono Soekanto. 1998. Sosiologi Suatu Pengantar. Jakarta: Rajawali Pers

Sumitro dkk. 2005. Pengantar Ilmu Pendidikan. Universitas Negeri Yogyakarta : Fakultas Ilmu Pendidikan

UU RI No. 14/2005 tentang Guru dan Dosen. Bandung : Citra Umbara. 